\title{
Regulation and action of insulin-like growth factors at the cellular level
}

\author{
BY L. S. PHILlips, J. B. HARP, S. GOLDSTEIN, J. KLEIN \\ AND C.-I. PAO \\ Division of Endocrinology and Metabolism, Department of Medicine, Emory University School of \\ Medicine, 69 Butler Street, SE, Atlanta, Georgia 30303, USA
}

Mammalian growth requires that nutrient utilization be directed towards energy storage, cell multiplication, and skeletal elongation. These processes demand metabolic fuels as substrates, together with the presence of systemic and local regulatory factors which channel nutrient utilization towards growth. Systemic regulators include traditional endocrine hormones such as growth hormone $(\mathrm{GH})$, insulin, the sex steroids, and thyroid hormone, as well as the insulin-like growth factors (IGFs) acting in an endocrine mode. Local growth factors include the IGFs acting in an autocrine-paracrine mode, as well as fibroblast growth factor, epidermal growth factor, nerve growth factor, plateletderived growth factor, the transforming growth factors, and many others. Our discussion will focus on the IGFs, which are of particular interest because of their critical role in both endocrine and autocrine-paracrine regulation of growth. Since systemic and local generation of IGFs is dependent on both nutritional and hormonal status, the IGFs act to 'amplify' nutritional and hormonal anabolic signals, facilitating the processes of energy storage, cell multiplication, and skcletal elongation.

\section{IGF STRUCTURE AND RECEPTOR STRUCTURE}

The IGFs resemble insulin in hormone structure, receptor structure, and action. Two IGFs have been characterized, IGF-1 and IGF-2. The gene for IGF-1 is located on chromosome 12, while the gene for IGF-2 is located on chromosome 11 (Brissenden et al. 1984). Both IGF-1 and IGF-2 consist of a single chain of amino acids with intrachain disulphide bridges, constituting an $\mathrm{A}$ - and $\mathrm{B}$-chain connected by a $\mathrm{C}$-peptide, and a terminal $D$ extension. The $A$ - and $B$-chains exhibit approximately $50 \%$ sequence homology with insulin but the $\mathrm{C}$-peptide and $\mathrm{D}$ extension are unlike insulin (Svoboda \& Van Wyk, 1985); the tertiary structure is thought to be similar to that of insulin as well (Blundell et al. 1983). Two forms of IGF receptors have been identified, a heterotetrameric Type I receptor which resembles the insulin receptor, and a monomeric Type II receptor which has a structure completely different from that of the insulin or the Type I IGF receptor (Nissley et al. 1985).

\section{IGF ACTION}

Both IGFs have broad, anabolic, insulin-like actions, including stimulation of multiplication of a wide variety of cells; promotion of processes related to energy storage, including amino acid transport and protein synthesis in muscle, glucose transport and formation of lipid in fat, and fatty acid synthesis in the liver; and stimulation of processes related to skeletal elongation, including synthesis of RNA, DNA, protein, and proteoglycan in chondrocytes and cartilage explants (Phillips \& Vassilopoulou-Sellin, 1980a,b). The IGFs previously were named 'somatomedins", based on their apparent mediation of 
the skeletal growth-promoting actions of $\mathrm{GH}$ (somatotropin), and the actions of the IGFs include negative feedback on GH release as well. Levels of IGF-2 appear to be high in fetal life, possibly reflecting function as a fetal growth factor, whereas adult animals generally have low circulating and tissue levels of IGF-2 except in the central nervous system, where IGF-2 may act as a neurotransmitter (Daughaday \& Rotwein, 1989). In contrast, levels of IGF-1 are low during fetal life, begin to increase shortly after delivery, and peak in humans during adolescence (Daughaday \& Rotwein, 1989). Since IGF-1 is much more sensitive than IGF-2 to metabolic status, subsequent discussion will emphasize the regulation and action of IGF-1.

Understanding of the mechanism of action of IGF-1 on target tissues generally has followed advances in understanding of insulin action, since the Type I IGF receptor resembles the insulin receptor and has particular affinity for IGF-1. By analogy with insulin action, binding of IGF-1 to the Type I IGF receptor may activate a cascade of cellular events, including both the generation of phosphoinositide-derived messenger molecules, which may permit rapid effects of IGF-1 on actions such as glucose transport, as well as phosphorylation of substrate proteins, which may mediate slower processes such as activation or inactivation of different genes. It seems likely that IGF-1 promotes the action of a phospholipase $C(E C$ 3.1.4.3), which hydrolyses cellular membrane phosphoinositides to form diacylglycerol and inositol phosphates, including inositol trisphosphate $\left(\mathrm{IP}_{3}\right)$; diacylglycerol activates protein kinase $\mathrm{C}(E C 2.7 .1 .37)$, whereas $\mathrm{IP}_{3}$ appears to promote the mobilization of $\mathrm{Ca}^{++}$from intracellular stores (Mooibroek \& Wang, 1988; Standaert \& Pollet, 1988). IGF-1-induced substrate phosphorylation is thought to mediate IGF-1 action at the level of the gene, including activation of transcription to form messenger RNA, translocation of messenger RNA from the nucleus to the cytoplasm, stabilization of messenger RNA in the cytoplasm, ribosomal translation of messenger RNA resulting in the synthesis of proteins, and intracellular processing of proteins (including glycosylation) to their mature forms. For example, the direct negative feedback of IGF-1 which decreases release of $\mathrm{GH}$ from the pituitary appears to be mediated by a decrease in the rate of transcription of the gene encoding GH messenger RNA (Yamashita \& Melmed, 1987).

\section{ENDOCRINE $v$ A AUTOCRINE-PARACRINE FORMATION}

IGF-1 appears to originate both in the liver and in extrahepatic sites. Presumably, hepatic origin and release into the circulation are involved with the endocrine actions of IGF-1, whereas local synthesis and release from extrahepatic tissues are involved with the autocrine-paracrine effects of IGF-1. While the liver is 50 - to 100 -fold enriched in IGF-1 messenger RNA compared with most extrahepatic tissues (Murphy et al. 1987), such enrichment may simply reflect the greater quantity of IGF-1 synthesis required for endocrine action $v$. autocrine-paracrine action, and conclusions cannot be drawn simply from messenger RNA levels as to the relative importance of systemic $v$. local actions. Thus, in both hepatic and extrahepatic tissues, synthesis of IGF-1 may constitute a 'switch' which promotes nutrient utilization for growth-related processes, involving both endocrine and autocrinc-paracrine mechanisms. Consistent with such a formulation, the synthesis of IGF-1 at both hepatic and extrahepatic sites appears to require the presence of regulatory hormones, suggesting that both systemic and local generation of IGF-1 as a growth factor can amplify the impact of traditional endocrine hormones. 


\section{ENDOCRINE ROLE OF IGF-I}

Understanding of the endocrine role of IGF-1 originally grew out of the recognition that IGF-1 appeared to mediate the skeletal growth-promoting effects of $\mathrm{GH}$; broader regulation of IGF-1 was appreciated only when it became apparent that IGF-1 levels did not parallel $\mathrm{GH}$ levels in a variety of human conditions and animal models of altered growth. Thus, early applications of IGF bioassays and IGF-1 immunoassays revealed low levels in GH deficiency and elevated levels in GH excess (acromegaly), consistent with the original 'somatomedin' hypothesis (Phillips \& Vassilipoulou-Sellin, 1980a,b: Daughaday \& Rotwein, 1989). However, subsequent studies revealed low levels of IGF biological activity in situations of 'poor growth despite GH' (diabetes, malnutrition, kidney failure, steroid excess), with normal levels in conditions of 'good growth without $\mathrm{GH}^{\circ}$ (obesity, and following surgery for hypothalamic tumours such as craniopharyngioma) (Phillips \& Vassilopoulou-Sellin, 1980a, b; Daughaday \& Rotwein, 1989). Common to these observations is a close association between circulating IGF bioactivity and hormonal and nutritional status, and not simply with GH levels alone.

$I G F$-binding proteins and inhibitors. It now appears that regulation of circulating IGF bioactivity involves modulation not only of levels of IGF-1, but also of levels of IGF-antagonistic factors; decreased circulating IGF biological activity in malnutrition, diabetes, kidney failure, and steroid excess appears to be due in part to elevated levels of IGF-binding proteins (Busby et al. 1988; Suikkari et al. 1988; Baxter \& Martin, 1989) and inhibitors (Phillips et al. 1989). The dynamics of regulation of these factors presently is best understood in terms of some of the IGF-binding proteins, of which the $25-\mathrm{kD}$ form (BP-1) appears to be particularly sensitive to insulin and nutritional status. Levels of $\mathrm{BP}-1$ rise severalfold in patients with poorly controlled diabetes, and fall promptly with insulin therapy (Suikkari et al. 1988). High molccular-weight (MW) IGF inhibitors appear to lower circulating IGFs bioactivity in diabetes, malnutrition, and steroid excess, while low-MW IGF inhibitors are more important in kidney failure (Phillips et al. 1989).

Nutritional modulation. At present, there is much more extensive understanding of the nutritional regulation of the IGFs than of the IGF-binding proteins or IGF inhibitors. Early studies in our laboratory showed that cartilage growth activity was decreased in food-restricted rats. Subsequent experiments then established that such cartilage remained responsive to stimulation by IGFs in serum, suggesting that the defect might lie in low circulating IGF activity. This was confirmed by direct bioassay examination; fasted rats exhibit a fall in circulating IGF bioactivity, which is restored promptly upon refeeding. Changes in IGF bioactivity are followed closely by changes in cartilage growth activity, suggesting a cause-and-effect relationship (Phillips \& Young, 1976).

The level of dietary protein appears to be particularly important in sustaining circulating levels of both IGF biological activity and immunoreactive IGF-1. Rats provided isoenergetic diets depleted in either fat, carbohydrate, or protein exhibit a fall in circulating IGF bioactivity only with the protein-depleted diet (Phillips et al. 1978). Levels of circulating IGF bioactivity and cartilage growth activity in such animals are comparable to values in other animals consuming $60 \%$ less energy of a balanced diet. Subsequent studies by Clemmons and co-workers (Clemmons et al. 1981; Isley et al. 1983) have confirmed the importance of dietary protein in sustaining circulating levels of IGF-1 in man. Human volunteers were fasted for 5-10 d, which reduced IGF-1, then refed diets with varying contents of protein and energy. Diets abundant in protein but restricted in energy permitted much better restoration of IGF-1 than diets deficient in 
both protein and energy, consistent with the hypothesis that protein is particularly important in sustaining levels of circulating IGF-1 as well as circulating IGF bioactivity.

Molecular regulation. More recent studies in our laboratory indicate that alterations in circulating IGF-1 in rats which are fasted and subsequently refed reflect underlying changes both in the activity of the IGF-1 gene, and perhaps also of tissue processing of precursor forms and release of the mature IGF-1 molecule. Goldstein et al. (1987a) have used specific cDNA probes to examine cellular levels of IGF-1 messenger RNA in rats which were fasted and subsequently refed. Fasting resulted in a $70 \%$ fall in IGF-1 messenger RNA, highly significant compared with control animals. Levels of IGF-1 messenger RNA began to rise with refeeding for as little as $3 \mathrm{~h}$, and were restored to normal levels after $48 \mathrm{~h}$ of refeeding. The rise in IGF-1 messenger RNA in the livers of fasted-refed rats was followed closely by rises in hepatic release of IGF-1 (Goldstein \& Phillips, 1989) and of hepatic content of a high-MW form of IGF-1, an apparent precursor molecule (Goldstein et al. 1987b).

Since deprivation of nutrients is associated with both a fall in levels of essential amino acids and changes in levels of circulating regulatory hormones, altered formation of IGF- 1 in the liver could be due to either of these groups of factors. Thus, an in vitro system is required to permit the effects of amino acids and hormones to be examined separately. Towards this objective, we have examined the production of IGF-1 by normal liver cells maintained in primary culture and exposed to insulin and amino acids in different combinations. When amino acid levels are fixed, exposure to insulin at levels within the physiological range of $10^{-10}-10^{-9} \mathrm{M}$ produces a significant rise in hepatocyte release of IGF-1 (Harp et al. 1989). Conversely, at a fixed concentration of insulin, an increase in the level of amino acids also leads to a significant rise in release of IGF-1. In combination, these observations indicate that insulin and amino acids can regulate hepatic production of IGF-1 independently.

To determine the potential molecular basis for the effects of essential amino acids on IGF-1, Harp et al. (1989) examined the release of IGF-1 and levels of IGF-1 messenger RNA in hepatocytes cultured for several days with or without individual amino acids. Although deprivation of the non-essential amino acid cysteine had no effect on hepatocyte release of IGF-1, deprivation of the essential amino acids lysine or tryptophan led to significant decreases in hepatocyte release of IGF-1. Such a fall in apparent IGF-1 formation could reflect simple deficiency of amino acids as a substrate for protein synthesis, but could also involve regulation of IGF-1 formation at the level of the gene. To explore the latter possibility, cellular levels of IGF-1 messenger RNA were determined via hybridization with specific cDNA probes. Tryptophan deprivation was associated with a $50 \%$ fall in cellular levels of IGF-1 messenger RNA, although there was no significant change in levels of messenger RNA for the structural protein, $\beta$-actin. These results indicate that the nutritional regulation of IGF-1 involves not only utilization of essential amino acids as a substrate for synthesis of the IGF-1 peptide, but also regulation of the cellular level of IGF-1 messenger RNA.

\section{AUTOCRINE-PARACRINE ROLE OF IGF-1}

Increasing evidence now indicates that growth facilitation by IGF-1 involves not only release by the liver and action in an endocrine mode, but also local production by a wide variety of tissues and action in an autocrine-paracrine mode. Early appreciation of such 
a role for IGF-1 stemmed from observations that cultured fibroblasts released immunoreactive IGF-1, and that such release could be facilitated by addition of $\mathrm{GH}$ (Adams et al. 1984). Although GH added to fibroblast cultures produced an increase in cell number, addition of a monoclonal antibody to IGF-1 blunted the ability of GH to stimulate fibroblast replication (Cook et al. 1988). This indicates that local formation of IGF-1 by fibroblasts is a necessary part of the mechanism by which $\mathrm{GH}$ stimulates cell multiplication in this system. Since exposure to GH also results in an increased release of IGF-1 by cultured chondrocytes (Smith et al. 1989), local production of IGF-1 may complement the $\mathrm{GH}$-induced stimulation of cartilage proliferation and skeletal elongation which is mediated largely by IGF-1 released by the liver and acting in an endocrine mode.

Local growth factor action in the gonads. Studies of the regulation of IGF-1 messenger RNA in tissues outside the liver indicate that levels of IGF-1 messenger RNA are regulated by factors other than $\mathrm{GH}$ in such tissues, and suggest that local production of IGF-1 may play a role in a wide spectrum of cellular events in addition to traditional growth processes. Studies by Murphy \& Friesen (1988) of the regulation of IGF-1 messenger RNA in both liver and uterus of ovariectomized-hypophysectomized rats indicate that molecular processes may be involved in the mechanism for IGF-1 regulation and action as a local growth factor. Thus, treatment of such animals with $\mathrm{GH}$ increased levels of IGF messenger RNA in both tissues, whereas treatment with oestrogen resulted in an increase in IGF-1 messenger RNA only in the uterus. This is consistent with the hypotheses that GH increases IGF-1 in all tissues as part of the process of GH-induced growth, and that IGF-1 may have a separate role related to the production or action of the sex steroids, or both.

$I G F-1$ in the testis. A potential role for IGF-1 as a local growth factor involved with production of sex steroids was first investigated in systems using cultured Leydig cells. These cells exhibit both receptors for the gonadotropin, luteinizing hormone (LH), and for IGF-1. Exposure to either the endocrine hormone LH (hCG) or IGF-1 downregulates its own receptor, but also results in a significant increase in the receptor for the other factor, suggesting that local secretion of IGF-1 by Leydig cells might potentiate the action of LH by increasing LH receptors (Perrard-Sapori et al. 1987). Consistent with such a proposed mechanism of action, addition of IGF-1 to Leydig cell cultures enhances the ability of LH to stimulate testosterone production by these cells (Kasson \& Hsueh, 1987). In combination, these observations suggest that local (autocrine-paracrine) production of IGF-1 in the testis can augment the systemic (endocrine) action of LH on this tissue to stimulate production of testosterone.

$I G F-1$ in the ovary. There is better understanding of the potential role of IGF-1 as a local growth factor in the ovary. In cultured granulosa cells, addition of either LH or follicle-stimulating hormone (FSH), alone or in combination, results in significant increases in secretion of IGF-1 (Hsu \& Hammond, 1987). Exposure to FSH also increases receptors for IGF-1 (Adashi et al. 1986), similar to the effects of LH on IGF-1 receptors in the male counterpart of granulosa cells, i.e., Leydig cells (Perrard-Sapori et al. 1987). Furthermore, addition of IGF-1 enhances the ability of FSH to promote binding of LH by granulosa cells (Adashi et al. 1985b), providing a potential mechanism for facilitation of LH action on these cells. Indeed, addition of IGF-1 also augments the ability of FSH to promote granulosa cell secretion of both progesterone and oestradiol as markers of gonadotropin action in this system (Adashi et al. 1985a; Mauro et al. 1988). 
Based on such observations, it seems likely that gonadotropin-induced local production of IGF-1 enhances gonadotropin action on target tissues, an example of IGF-1 acting as a growth factor in an autocrine-paracrine mode. It appears that the action of LH on both granulosa cells (in the ovary) and Leydig cells (in the testis) results in an increase in both IGF-1 receptors and IGF-1 production, with the effect being an increase in IGF-1 action. Since IGF-1 in turn increases receptors for $\mathrm{LH}$ or FSH, or both, and facilitates gonadotropin-induced steroid production, the net effect is that of amplifying LH or FSH action, or both, in this system.

\section{SUMMARY}

Present understanding of IGF-1 as a growth factor mediating integration of nutritionalhormonal interactions indicates that IGF-1 acts in both an endocrine mode on distant targets and an autocrine-paracrine mode on local targets. In the liver, the combined presence of $\mathrm{GH}$, insulin, and critical metabolic fuels such as essential amino acids results in increased levels of IGF-1 messenger RNA, increased production of a high-MW IGF-1 precursor, and increased release of IGF-1 into the circulation, permitting action on distant target tissues bearing specific receptors for IGF-1. The net effect is distant amplification of anabolic hormone action via IGF-1 acting in an endocrine mode. In extrahepatic tissues, both 'general' anabolic hormones (insulin and $\mathrm{GH}$ ) as well as 'specific' hormones (e.g. gonadotropins) acting on a wide variety of targets (including fibroblasts and chondrocytes as well as granulosa and Leydig cells) promote both local secretion of IGF-1 and an increase in IGF-1 receptors. Local actions of IGF-1 then result in a secondary increase in both hormone receptors and hormone responses. The net effect is local amplification of hormone action via IGF-1 acting as a growth factor in an autocrine-paracrine mode.

\section{CONCLUSION}

The IGFs are insulin-like peptides with broad, anabolic, insulin-like actions on a wide variety of tissues. These growth factors are secreted by the liver as systemic hormones acting in an endocrine mode, and respond both to traditional endocrine hormones such as $\mathrm{GH}$ and insulin, as well as to the presence of critical metabolic fuels. Regulation in the liver according to nutritional status appears to extend beyond the simple availability of substrates for protein synthesis, and involves modulation of IGF-1 production at the level of messenger RNA. In extrahepatic tissues, the IGF appear to act in an autocrine-paracrine mode as local growth factors which amplify tissue response to specific hormones such as LH and FSH, in addition to general anabolic hormones such as GH and insulin. The endocrine and autocrine-paracrine actions of the IGF appear to be modulated additionally by changes in IGF-binding proteins and by IGF inhibitors, both regulated in turn by nutritional-hormonal status. Thus, present understanding of mechanisms of growth includes appreciation of the local and systemic production of growth factors and antagonists, which can amplify the impact of hormones and nutritional status. Direct manipulation of growth factors may, thus, offer a separate avenue for regulation of growth.

This work was supported in part by awards DK-33475 and DK-34785 from the National Institutes of Health. 


\section{REFERENCES}

Adams, S. O., Kapadia, M., Mills, B. \& Daughaday, W. H. (1984). Releasc of insulin-like growth factors and binding protein activity into serum-free medium of cultured human fibroblasts. Endocrinology 115 , 520-526.

Adashi, E. Y., Resnick, C. E. \& Svoboda, M. E. (1985a). Somatomedin-C synergizes with follicle-stimulating hormone in the acquisition of protestin biosynthetic capacity by cultured rat granulosa cells. Endocrinology 116, 2135-2142.

Adashi, E. Y., Resnick, C. E., Sroboda, M. E. \& Van Wyk, J. J. (1985b). Somatomedin-C enhances induction of luteinizing hormone receptors by follicle-stimulating hormone cultured rat granulosa cells. Endocrinology 116, 2369-2375.

Adashi, E. Y., Resnick, C. E.. Svoboda. M. E. \& Van Wyk, J. J. (1986). Follicle-stimulating hormone enhances somatomedin $C$ binding to cultured rat granulosa cells. Journal of Biological Chemistry 261. 3923-3926.

Baxter, R. C. \& Martin, J. L. (1989). Binding proteins for the insulin-like growth factors: structure, regulation and function. Progress in Growth Factor Research 1. 49-68.

Blundell, T. L., Bedarkar, S. \& Humbel, R. E. (1983). Tertiary structures, receptor binding, and antigenicity of insulin like growth factors. Federation Proceedings 42, 2592-2597.

Brissenden, J. E., Ullrich, A. \& Francke, U. (1984). Human chromosomal mapping of genes for insulin-like growth factors I and II and epidermal growth factor. Nature 310, 781-784.

Busby, W. H., Snyder, D. K. \& Clemmons, D. R. (1988). Radioimmunoassay of a 26,000-dalton plasma insulin-like growth factor-binding protein: control by nutritional variables. Journal of Clinical Endocrinology and Metabolism 67, 1225.

Clemmons, D. R., Klibanski, A., Underwood, L. E., McArthur, J. W., Ridgway, E. C., Beitins, I. Z. \& Van Wyk, J. J. (1981). Reduction of plasma immunoreactive somatomedin-C during fasting in humans. Journal of Clinical Endocrinology and Metabolism 53, 1247-1250.

Cook, J. J., Haynes, K. M. \& Werther, G. A. (1988). Mitogenic effects of growth hormone in cultured human fibroblasts: evidence for action via local insulin-like growth factor 1 production. Journal of Clinical Investigation 81, 206-212.

Daughaday. W. H. \& Rotwein, R. (1989). Insulin-like growth factors I and II. Peptide, messenger ribonucleic acid and gene structures, serum, and tissue concentrations. Endocrine Review 10, 68-91.

Goldstein, S., Amendt, L. M., Dawson, P. E. \& Phillips, L. S. (1987a). Regulation of hepatic somatomedin-C content and IGF-1 mRNA in fasting and refeeding. Clinical Research 35, 23A Abstr.

Goldstein, S., Amendt, L. M. \& Phillips, L. S. (1987b). Immunoreactivity and bioactivity of a high-MW putative hepatic somatomedin precursor. Diabetes 36, Suppl., 94A Abstr.

Goldstein, S. \& Phillips, L. S. (1989). Nutrition and Somatomedin XVIII. Nutritionally-regulated release of somatomedins and somatomedin inhibitors from perfused livers in rats. Metabolism 38, 745-752.

Harp, J. B., Goldstein, S., Sertich, G. J. \& Phillips, L. S. (1989). Regulation of hepatic IGF-1 production by amino acids. Clinical Research 37, 36A Abstr.

Hsu, C.-J. \& Hammond, J. M. (1987). Gonadotropins and estradiol stimulate immunoreactive insulin-like growth factor-I production by porcine granulosa cells in vitro. Endocrinology 120, 198-207.

Isley, W. L., Underwood, L. E. \& Clemmons, D. R. (1983). Dietary components that regulate serum somatomedin-C concentrations in humans. Journal of Clinical Investigation 71, 175-182.

Kasson, B. G. \& Hsuch, A. J. W. (1987). Insulin-like growth factor-I augments gonadotropin-stimulated androgen biosynthesis by cultured rat testicular cells. Molecular and Cellular Endocrinology 52, 27-34.

Mauro, T., Hayashi, M., Matsuo, H., Ueda, Y., Morikawa, H. \& Mochizuki, M. (1988). Comparison of the facilitative roles of insulin and insulin-like growth factor $I$ in the function differentiation of granulosa cells: in vitro studies with the porcine model. Acta Endocrinologica (Copenhagen) 117, 230-240.

Mooibroek. M. J. \& Wang, J. H. (1988). Integration of signal-transduction processes. Biochemical and Cellular Biology 66, 557-566.

Murphy, L. J., Bell, G. I. \& Friesen, H. G. (1987). Tissue distribution of insulin-like growth factor I and II messenger ribonucleic acid in the adult rat. Endocrinology 120, 1279-1282.

Murphy. L. J. \& Friesen, H. G. (1988). Differential effects of estrogen and growth hormone on uterine and hepatic insulin-like growth factor I gene expression in the ovariectomized hypophysectomized rat. Endocrinology 122, 325-332.

Nissley, S. P., Haskell, J. F., Sasaki, N., DeVroede. M. A. \& Rechler, M. M. (1985). Insulin-like growth factors receptors. Journal of Cell Science 3, 39-51. 
Perrard-Sapori, M.-H., Chatelain, P. G., Jaillard, C. \& Saez, J. M. (1987). Characterization and regulation of somatomedin-C/insulin-like growth factor $\mathrm{I}(\mathrm{Sm}-\mathrm{C} / \mathrm{lGF}-1)$ receptors on cultured pig Leydig cells. European Journal of Biochemistry 165, 209-214.

Phillips, L. S., Goldstein, S. \& Klein, J. D. (1989). Somatomedin inhibitors. In Molecular and Cellular Aspects of IGF-I, pp. 81-95 [D. LeRoith and M. K. Raizada, editors]. New York: Plenum Publishing Co.

Phillips, L. S., Orawski, A. T. \& Belosky, D. C. (1978). Somatomedin and nutrition. IV. Regulation of somatomedin activity and growth cartilage activity by quantity and composition of diet in rats. Endocrinology 103. 121-127.

Phillips, L. S. \& Vassilopoulou-Sellin, R. (1980a). Somatomedins. New England Journal of Medicine 302, $371-380$.

Phillips, L. S. \& Vassilopoulou-Sellin, R. (1980b). Somatomedins. New England Journal of Medicine 302, 438-446,

Phillips, L. S. \& Young, H. S. (1976). Nutrition and somatomedin. I. Effect of fasting and refeeding on serum somatomedin activity and cartilage growth activity in rats. Endocrinology 99, 304-314.

Smith, R. L.. Palathumpat, M. V., Ku, C. W. \& Hintz, R. L. (1989). Growth hormone stimulates insulin-like growth factor I actions on adult articular chondrocytes. Journal of Orthopaedic Research 7, 198-207.

Standaert, M. L. \& Pollet, R. J. (1988). Insulin-glycerolipid mediators and gene expression. FASEB Journal 2, 2453-2461.

Suikkari, A.-M., Koivisto, V. A., Rutanen, E.-M., Yki-Jarvinen, H., Karonen, S.-L. \& Seppala, M. (1988). Insulin regulates the serum levels of low molecular weight insulin-like growth factor-binding protein. Journal of Clinical Endocrinology and Metabolism 66. 266-272.

Svoboda, M. E. \& Van Wyk, J. J. (1985). Purification of somatomedin-C/insulin-like growth factor I. Methods of Enzymology 109, 798-817.

Yamashita, S. \& Melmed, S. (1987). Insulin-like growth factor I regulation of growth hormone gene transcription in primary rat pituitary cells. Journal of Clinical Investigation $79,449-452$. 